\title{
A Estética do Corpo na FiLOSOFIa E Na ARte Da IdADE Média: TeXTo E IMAGEM
}

\author{
Ricardo Luiz Silveira da Costa ${ }^{1}$
}

RESUMO: A ideia de beleza - e sua consequente fruição estética - variou conforme as transformaçôes das sociedades humanas, no tempo. Durante a Idade Média, coexistiram diversas concepçōes de qual era o papel do corpo na hierarquia dos valores estéticos, tanto na Filosofia quanto na Arte. Nossa proposta é apresentar a estética do corpo medieval que alguns filósofos desenvolveram em seus tratados (particularmente Isidoro de Sevilha, Hildegarda de Bingen, João de Salisbury, Bernardo de Claraval e Tomás de Aquino), além de algumas representaçóes corporais nas imagens medievais (iluminuras e esculturas), e assim analisar o tema em três vertentes: a) o corpo como cárcere da alma, b) o corpo como instrumento, e c) o corpo como desregramento.

PALAVRAS-CHAVE: Estética. Corpo. Idade Média. Filosofia Medieval.

\section{DA DILACERAÇÁO BACONIANA AO MICROCOSMO DO MUNDO}

Imagem 1

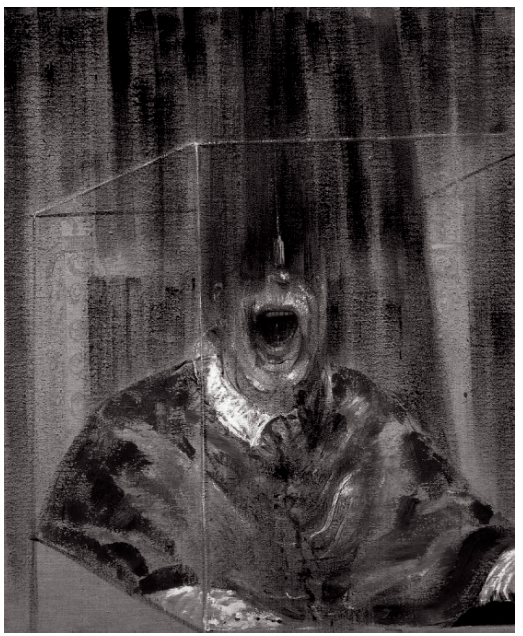

A Cabeça VI (1949), de Francis Bacon (1909-1992), talvez seja a mais notável e dramática representação artística da desintegração do corpo no século

\footnotetext{
${ }^{1}$ Universidade Federal do Espírito Santo (UFES). E-mail: ricardo@ricardocosta.com
} 
XX, da fragilidade do ser. Tensão, angústia, morbidez, terror, sofrimento, dor: o corpo não sairia ileso das dilacerantes especulações filosóficas de nosso tempo. No quadro, a cabeça, tradicional, locus da razão, se desfaz, enquanto o torturado papa se decompóe. Os contrastes das cores escolhidas pelo artista acentuam a tensão dramática da cena. $\mathrm{O}$ mais significativo de tudo é que o quadro pretende ser um estudo a partir de um quadro de Velázquez (15991660) do Papa Inocêncio X (1574-1655). Bacon pretendia ser o Velázquez do século XX.

Mas, por que principiar o tema sobre o corpo na Idade Média com um quadro do pintor (e ateu convicto) Francis Bacon (1909-1992), amante do grotesco, do angustiante e do desespero eufórico? Simples. Trata-se de uma antítese. Tradição versus Revolução. Idade Média versus Modernismo (mas também Pós-Modernismo). Com seu horror alçado à categoria de arte como choque visceral, Bacon é o mais digno representante da declaração trágica do corpo, do ser, no século XX.

Em diametral oposição, o mundo da tradição filosófica (e artística) medieval alçou o corpo à condição de centro da Criaçáo divina. Embora tenham recebido da Antiguidade, como herança filosófica grega (platônica), a negação do corpo - o corpo como cárcere, prisão, tolhimento da alma - os medievais contrapuseram a essa tradição o corpo como entrecruzamento das linhas de força do Universo, microcosmo do mundo.

O exemplo medieval mais famoso do homem-microcosmo é a imagem que a monja Hildegarda de Bingen (1098-1179) teve, em uma de suas visóes. $\mathrm{Na}$ obra Liber divinorum operum (O Livro das obras divinas, c. 1163-1173), a estrutura do Universo tem uma direta correspondência com a fisiologia humana. Nessa perspectiva, os atos humanos repercutem e cooperam (ou não) na ordem do cosmos. 
Imagem 2

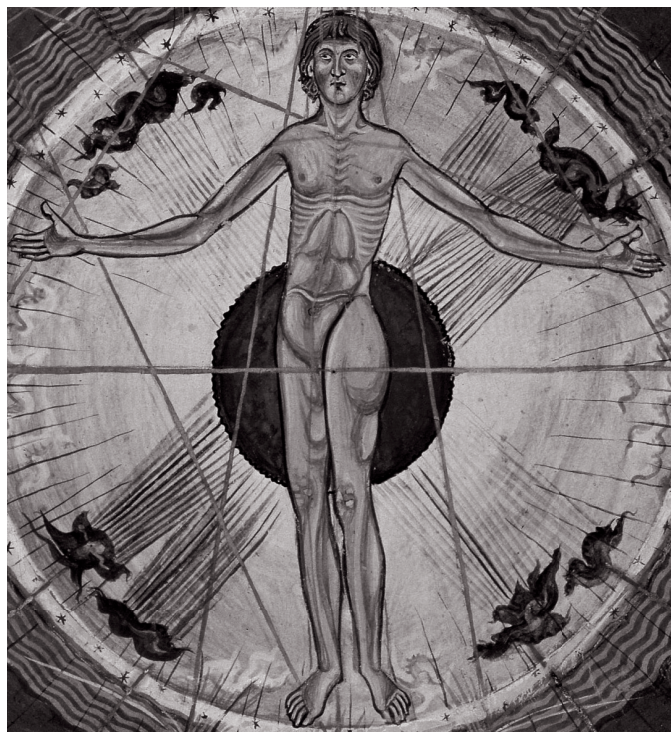

Liber divinorum operum, iluminura 2, folio 9: O espírito do mundo e a roda (detalhe), séc. XIII.

O Livro das Obras Divinas é dividido em três partes. A primeira ("O Mundo da Humanidade”) dedica uma seção ao homem - A natureza humana. O homem é o centro da criação divina. Como na iluminura correspondente àquela visão (imagem 2), o homem é jovem, delgado, íntegro. Suas pernas são robustas. Com os braços abertos para o Universo, ele recebe a influência dos quatro ventos (Levante, Austral, Ocidente e Norte) e dos sete planetas então considerados (Lua, Mercúrio, Sol, Marte, Júpiter e Saturno). Seu corpo expressa a intercessão do próprio Cosmo: a cabeça (esférica) representa o poder da Humanidade; os olhos, a porta de acesso ao conhecimento; os ouvidos permitem o desfrute dos sons da Glória dos mistérios; o nariz aprecia o agradável perfume da ordem das obras; e a boca é o instrumento da palavra divina criadora. Na passagem da obra que aborda aquela visão do homem, há uma explicação de sua posição central no Universo:

Por fim, e no centro da roda, surge a imagem de um homem, cuja cabeça alcança a parte superior e os pés a parte inferior do círculo de ar denso, branco e luminoso. À direita, as pontas dos dedos de sua mão direita; à esquerda, as pontas dos dedos de sua mão esquerda estáo 
estiradas e alcançam o mesmo círculo, tocando dois pontos diferentes da circunferência.

O motivo pelo qual a imagem estendeu os braços é porque o homem está no centro na estrutura do mundo, já que é mais poderoso que todas as outras criaturas que se encontram na própria estrutura. Embora seja de pequena estatura, é grande pela energia de sua alma, e como tem a capacidade de mover a cabeça para cima e os pés para baixo, alcança tanto os elementos superiores quando os inferiores, e assim pode movê-los. (HILDEGARDA DE BINGEN, Segunda visão, XV).

\section{A METÁfOrA ORGANICISTA}

Essa intercessão transcendental da imagem humana já estava presente na mesma época em um dos tratados filosóficos medievais mais importantes (do período pré-escolástico): o Policraticus (c. 1159) de João de Salisbury (c. 1120-1180). Neste que é considerado o primeiro texto de filosofia política ocidental, há uma famosíssima passagem em que a sociedade é comparada ao corpo humano:

Na comunidade política, o príncipe ocupa o lugar da cabeça, e se encontra sujeito somente a Deus e a quem, em nome d'Ele, faz seu papel na terra, da mesma forma que, no corpo humano, a mesma cabeça têm vida e é governada pela alma. O Senado ocupa o lugar do coraçáo, já que dele procedem os começos dos atos bons e maus. Os juízes e os governadores das províncias reclamam para si a missão dos olhos, dos ouvidos e da língua. Os oficiais e os soldados correspondem às máos. Os que assistem ao príncipe de modo estável são semelhantes aos flancos. Os questores e escrivães - não os que controlam os cárceres, mas os encarregados do erário privado do príncipe - podem ser comparados ao ventre e aos intestinos. Se estes sáo congestionados por uma desmedida avidez e retêm com excessivo empenho o que acumularam, provocam inumeráveis e incuráveis doenças, até que essa dor traga a destruição de todo o corpo.

Os agricultores se parecem aos pés, pois também se encontram continuamente no solo. Para eles é especialmente necessária a atençáo da cabeça, já que tropeçam em muitas dificuldades enquanto pisam a terra com o trabalho de seu corpo, e merecem ser protegidos com tanta ou mais justa proteçáo para se manterem de pé, sustentarem e moverem todo o corpo. Retire de qualquer corpo essas peças dos pés que, por mais robusto que ele seja, não poderá caminhar por suas próprias forças, mas tentará se arrastar torpemente com as mãos, sem consegui-lo e com grande fadiga, ou só poderá se mover com o auxílio das bestas. (JUAN DE SALISBURY, Livro V, 2, 6). 
Da passagem, não posso deixar de ressaltar a importância que a filosofia política de Salisbury dá à base da sociedade: os camponeses. O poder, sob a influência do pensamento filosófico cristão, deveria atentar para os mais necessitados - "[...] para eles, é especialmente necessária a atenção da cabeça..." As duas extremidades do corpo eram assim unidas pela razão filosófica préescolástica.

O que a filosofia de João de Salisbury ressaltava, a arte exprimia: a Idade Média foi um dos períodos da Humanidade em que os contatos sociais entre as ditas "classes dirigentes" e o "povo" foram mais estreitos. Seu patrimônio artístico o prova, pois o camponês está em toda a parte, como já nos recordou a historiadora Régine Pernoud (1909-1998) - nos quadros, nas tapeçarias, nas esculturas das catedrais, nos vitrais (como o da imagem 3, da Catedral de Chartres).

Imagem 3

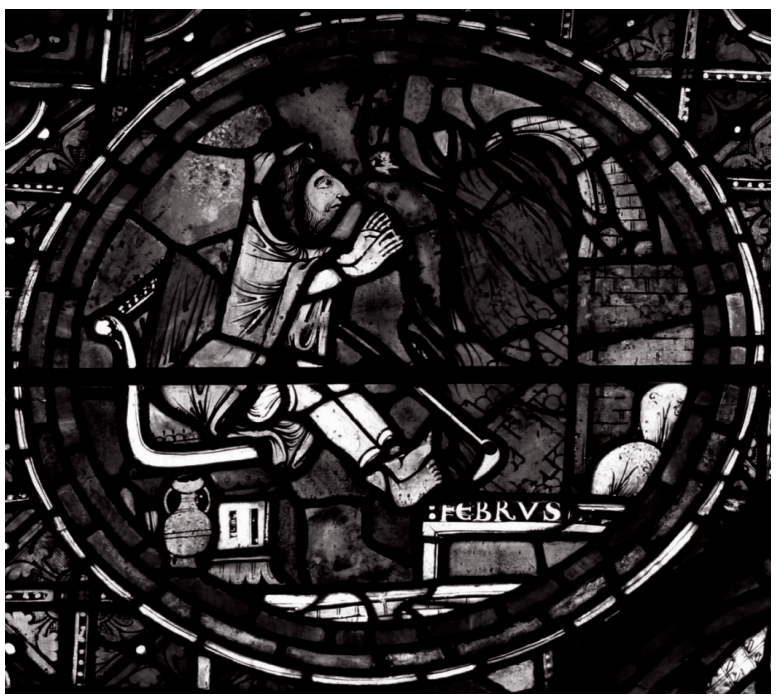

O vitral representa o trabalho no mês de fevereiro: o camponês descansa. Estende as mãos e os pés em sua lareira. Aquece seus instrumentos de trabalho. Relaxa. O fogo é intenso. Há madeira em abundância. A Igreja preocupava-se com seus pobres; a Filosofia, com a perfeita plasticidade do corpo social. A vida deveria ser pulsante; o corpo deveria se valer de toda a sua extensão física - só assim suas partes poderiam viver em uma viva conexão existencial. 
Além de sintetizar toda a criação divina e estar no entrelaçamento de todos os níveis do Universo, o corpo representava a própria sociedade em movimento, sua organicidade. A Idade Média era, nesse aspecto, uma festa: em seu calendário, os feriados reuniam as ordens. Nos níveis sociais mais elevados, o corpo era visto, sentido e, sobretudo, exposto nas reunióes sociais, nas cortes, como, por exemplo, a procissáo corporal que pode ser apreciada em uma iluminura do Roman d'Alexandre (cópia do séc. XII). Os corpos em sociedade.

Imagem 4

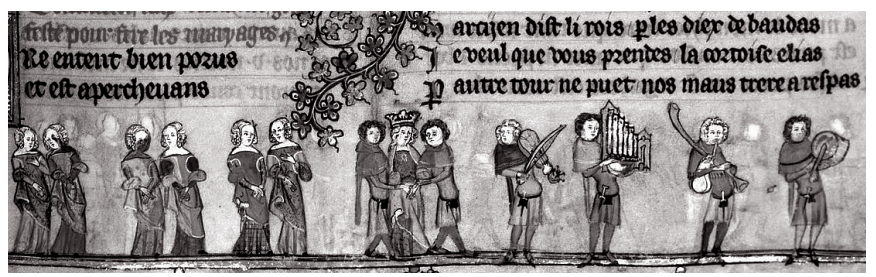

Como o homem-macrocosmo de Hildegarda de Bingen, os corpos em desfile da iluminura do Roman d'Alexandre são delgados, elegantes, coloridos. Trata-se de uma procissão laica. Profana. São corpos jovens! Nunca devemos perder de vista a juventude do mundo medieval. No centro da mundanidade, a cabeça do corpo social - o rei (conduzido por seus dois pajens) -; à sua esquerda, seis damas conversam animadamente; à direita, quatro músicos entretêm o ambiente.

\section{O CORPO SUJEITADO}

No entanto, não devemos imaginar que somente com o Renascimento do século XII houve uma redescoberta do corpo. A estética corporal sempre foi objeto de consideração pelos pensadores medievais. Já no século VII, Isidoro de Sevilha (560-636) fizera sua própria definição do corpo - e sua imbricação com os quatro elementos (fogo, água, terra, ar), ideia herdada da medicina grega. Seu tom é essencialmente "científico", sem qualquer desconsideração da materialidade corporal:

O corpo é denominado assim porque, ao se corromper, perece. É decomposto e mortal, e deve se dissolver. Por sua vez, carne é uma palavra derivada de criar (creare). O sêmen do macho é denominado crementum, pois a partir dele se concebem os corpos dos animais e dos homens. Por 
isso, os pais são chamados "criadores". A carne está integrada pelos quatro elementos: é terra porque tem carne; ar, na respiração; líquido, no sangue, e fogo, no calor vital. Cada um desses elementos ocupa sua parte própria, e retorna à sua essência quando a integridade corporal se dissolve.

O significado de "carne" e de "corpo" é diferente. A carne sempre é corpo, mas nem sempre o corpo é carne. A carne tem vida enquanto vive no corpo. O corpo que não vive não é carne. Assim se dá o nome de "corpo" ao que está morto depois da vida ou ao que nasceu sem ela. É comum ver corpos com vida, mas carentes de carne, como a erva ou as árvores [...] A parte fundamental do corpo é a cabeça. E se chama caput porque nela têm origem todos os sentidos e todos os nervos, e porque dela procede todo o princípio da vida. Nela se encontram todos os sentidos, e ela é como a personificação da alma, que vela pelo corpo. (ISIDORO DE SEVILHA. Etimologias, XI, 14-17 e 25).

Imagem 5

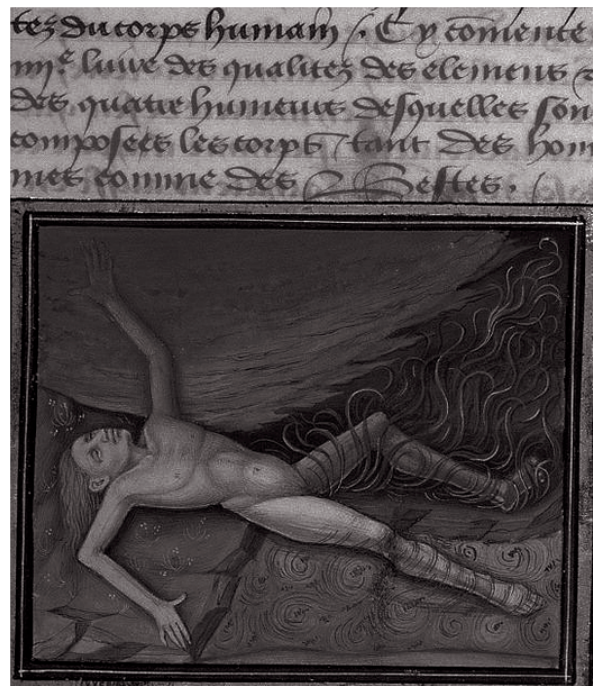

A sujeição do corpo aos quatro elementos, tal como a descreve Isidoro de Sevilha, está muito bem expressa iconograficamente em uma iluminura (folio 91) do século XV do Livro das propriedades das coisas (De proprietatibus rerum), obra enciclopédica escrita em 1240 por Bartolomeu de Glanville, conhecido como o Inglês (c. 1202-1271). Seja como for, fosse qual fosse o grau de sujeição com que o pensador idealizasse o corpo em sua relação com os 
quatro elementos vitais, o fato é que ele era considerado o centro da realidade, cerne da existência, vida pulsante - e, por isso, necessitava ser domesticado, racionalizado, civilizado. Ademais, percebe-se nessa passagem das Etimologias a notável transformação que o pensamento filosófico ocidental processou em relação ao corpo: da concepçáo platônica de cárcere da alma, ele passou a ser pensado como a própria intercessáo da vida.

\section{O CORPO SUbLIMADO: PALÁCIO DA ALMA}

A crescente valorização do corpo na Idade Média teve em Bernardo de Claraval (1090-1153) a ponte filosófico-literária mais representativa e que faria o pensamento ocidental desembocar na Escolástica do século XIII. Em várias passagens da obra do cisterciense, nota-se esse clímax. E, curioso observar, o cárcere platônico é invertido: agora, o corpo é uma casa sublime:

$\mathrm{Tu}$, alma, vives em uma casa sublime, fabricada pessoalmente pelo próprio Deus. Refiro-me a teu corpo, táo bem idealizado, disposto e ordenado, que te serve como uma morada gloriosa e deleitável, e que para teu corpo construiu outro excelso, amplíssimo e encantador palácio, que é esse mundo sensível e habitável. (BERNARDO DE CLARAVAL. Sermão segundo dedicado à Igreja, 1).

No século XII, o corpo é percebido como uma mansão. Um deleite para os sentidos. Maravilhoso, a disposição de suas partes é esteticamente louvada. Essa linha de força de natureza platônica - mesmo que em um platonismo matizado, invertido - proporcionará o que os especialistas nomearam humanismo cristão. Essa nova corrente filosófica estetiza o corpo, torna-o passível de apreciação, de deleite estético. Na Arte, sua materialização ensejou delicadas obras esculturais, como, por exemplo, o Adão de Cluny (c. 1260), verdadeiro precursor das obras de arte do Humanismo moderno. 
Imagem 6

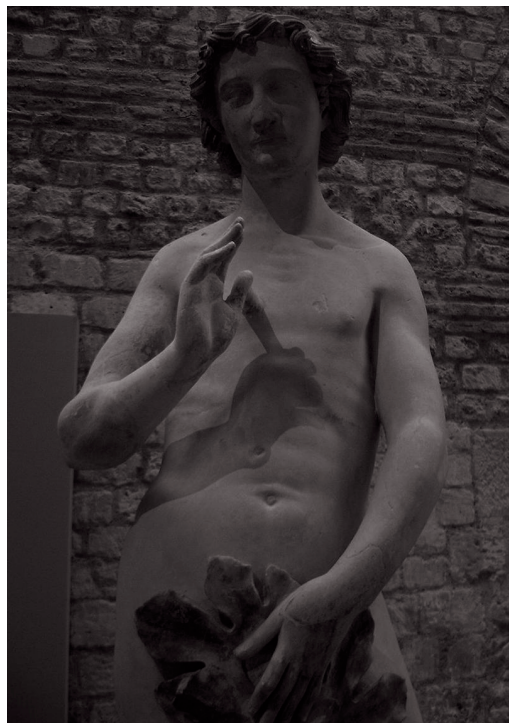

A morada da alma expressa (ou não) a beleza de sua forma interior:

Quando a luz da beleza [da honesta consciência] inunda copiosamente o recôndito do coraçáo, manifesta-se exteriormente como uma lâmpada que ardia sob o alqueire; ela é forte como a luz que brilha nas trevas - e não pode ser ocultada. $\mathrm{O}$ corpo é atraído por essa imagem da mente que irrompe com seus raios e se difunde por seus membros e sentidos de modo que toda obra, palavra, aspecto, movimento e sorriso são impregnados de gravidade e honestidade.

A beleza da alma, caso não haja dubiedade em seu espírito, se manifesta nestes e em outros movimentos dos membros e sentidos corporais, gestos e costumes, quando exteriorizam sobriedade, pureza, modéstia, ausência de qualquer lascívia e insolência; ela é alheia à superficialidade e indolência, e se acomoda à justiça que é ditada pela piedade, mesmo que tudo isso seja um simulacro não inteiramente correspondente àquilo que transborda de seu coração. (BERNARDO DE CLARAVAL. Sobre o Cantar dos Cantares, LXXXV, 11). 
Em contrapartida - e exatamente por ser um palácio excelso da alma, perfeito - é que o corpo deveria ser sempre vigiado pela razão, domesticado, disciplinado, ter suas paixóes contidas, refreadas:

Os quatro delitos do corpo são: a curiosidade dos olhos, a loquacidade da língua, a crueldade das máos e o prazer lascivo. $O$ corpo foi confeccionado por quatro elementos: o fogo, que sempre tende a subir e dá brilho aos olhos; o ar, que separa e forma as palavras; a terra, que confere a corpulência; a água, que traz a abundância dos humores naturais. A curiosidade nasce do descaramento do olhar; a loquacidade, de uma língua rápida; a crueldade (ou dureza) de uma corpulência insensata. Tudo isso se manifesta nos animais, que quanto mais se guiam por sua natureza, mais ferozes e cruéis são. A paixão da luxúria brota do humor natural. (BERNARDO DE CLARAVAL. Terceira série de sentenças, 9).

Essas digressôes filosóficas de contenção corporal por vezes reacendiam sua raiz platônica. Por exemplo, em uma de suas metáforas corporais, Bernardo resgatou a imagem do corpo como uma prisão da alma:

Aceitemos a sabedoria popular: quem guarda o corpo, defende um bom castelo. Que vigilância necessita esse castelo? Crês que a alma defende bem o castelo de seu corpo se seus membros conspiram e se entregam ao inimigo? (BERNARDO DE CLARAVAL. Sermão segundo na Assunção da Santa Maria, 3).

A alma tem dois muros: um interior, outro exterior. $\mathrm{O}$ muro interior é a ira natural, isto é, a força da alma [...] O muro exterior é o corpo, que encerra a alma e a mantém encarcerada [...] Aprisionada pelo muro exterior, algumas vezes consente com as baixezas das seduçôes carnais. (BERNARDO DE CLARAVAL. Terceira série de sentenças, 77).

O corpo não poderia estar desordenado. Era de natureza nobre demais para ser assim rebaixado. Seu desregramento, portanto, era a suma preocupação da Filosofia Medieval. A fonte dos distúrbios eram os sentidos - como Platão (c. 424-347 a. C.) fez escola! Todas as consideraçôes filosóficas depreciativas (ou normativas, como queiram) em relação ao corpo na Idade Média tinham como base a filosofia platônica. Acrescida a ela, como já destaquei, a metáfora organicista, que ressaltava a importância do bom cumprimento das partes, para que o todo estivesse saudável. Bernardo manteve essa tradição. $\mathrm{Na}$ Terceira série de sentenças, ao denunciar a corrupção na Igreja, ele fez uma dura admoestação: 
Cristo e a Igreja são um só corpo. Cristo é a cabeça; a Igreja, o corpo [...] Os olhos desse corpo que devem se preocupar com os membros inferiores são os bispos. Eles são olhos e pastores [...] O nariz são os arcediagos que, com penetrante olfato, devem conhecer a vida dos demais e informar ao bispo. As orelhas são os decanos, que devem ouvir os juízos e proferir as sentenças [...] Boca e língua são os presbíteros e diáconos, pregadores da palavra de Deus.

Assim deveria ser, mas agora está tudo confuso e preterido. Não se levantam mais os olhos, pois eles se abaixaram em direção aos próprios interesses, ao ódio, à simpatia, e se cumpriram estas palavras: 'As trevas cobriam o abismo' [...] O nariz perdeu o olfato por apreciar a maldade em troca do bem [...] As orelhas perverteram a justiça; a língua e a boca silenciaram.

O peito, o dorso, os braços e as mãos são os soldados da Igreja. No peito está o coração, sede da audácia [...] O dorso serve para carregar os homens, levantar os braços e manejar as máos.

Mas tudo está tresloucado. Como são perversas essas mãos que desgarram e arrancam os olhos que deveriam limpar, destroem o nariz que deveriam purificar, amputam as orelhas que deveriam lavar, cerram as máos que deveriam abrir para servir! Nos banquetes surgem críticas sobre a vida dos clérigos, e nas reunióes públicas sérias são as discórdias por sua causa!

O ventre, tido como a parte vil por sua lassidão, é receptáculo de alimentos, nutridor do corpo; transforma a comida e distribui seu suco vital entre os membros superiores e inferiores. $\mathrm{O}$ ventre da Igreja são os monges e eremitas desprezados pelo mundo. Eles recebem o alimento espiritual da doutrina. São o fundamento da Igreja [...] A eles se aplica o provérbio: "O gênero humano subsiste graças a uns poucos”. Porque se eles desaparecessem, o mundo pereceria por um raio ou por uma rachadura da terra.

Os pés que suportam todo o corpo são os rústicos, de cujo trabalho vivem todos demais. Essa é a concatenação da Igreja, se quer estar unida à sua cabeça. (BERNARDO DE CLARAVAL. Terceira Série de Sentenças, 118).

\section{O CORPO, COPRINCÍPIO ESSENCIAL DO ENTE HUMANO}

Um homem é belo quando seus membros mantêm uma proporção decente no que se refere à quantidade e posição, e quando sua cor é clara e nítida. Consequentemente, em relação às demais coisas deve-se conceber, proporcionalmente, que algo é belo quando possui a claridade própria de seu gênero, espiritual ou corporal, e quando está constituído conforme uma proporção devida. (TOMÁS DE AQUINO. Expositio in Dionysium de divinis nominibus, 362). 
Ao ser expresso em termos filosóficos, o corpo foi representado como um instrumento metafórico, alegoria filosófica que personificava a sociedade e suas mazelas - suas doenças, crises, desvios. Centro da criação, tinha um papel primordial na filosofia cristã. O próprio Cristo dissera que o pão era Seu corpo: "E tomou um pão, deu graças, partiu e distribuiu-o a eles, dizendo: 'Isto é o meu corpo que é dado a vós. Fazei isto em minha memória.” (Lc, 22, 19). Por isso, usava-se o corpo como ponto de partida das reflexóes transcendentais. E a filosoficamente mais elevada foi a de Tomás de Aquino (1225-1274). Nela, o corpo foi apresentado como um dos elementos essenciais do ente humano, raiz de um grande número de potências e atividades sensitivas. Belo. Mesmo as potências intelectivas (a inteligência e a vontade), para o Aquinate, fazem instrumentalmente uso do corpo para obter suas atividades.

Assim, o querer e o entender humanos precisam do material subministrado pelas potências sensitivas externas (os sentidos: tato, olfato, visão, audição e paladar) e internas (o senso comum, a memória, a imaginação e a potência cogitativa). Ele afirma:

O primeiro princípio pelo qual opera um ser é a forma, à qual se atribui propriamente a ação. [...] É evidente que o primeiro princípio pelo qual o corpo vive é a alma. [...] A alma é o primeiro princípio pelo qual nos alimentamos, sentimos e nos movemos localmente; e é também o primeiro pelo qual entendemos. (TOMÁS DE AQUINO).

Corpo e alma são os coprincípios essenciais do ente humano, e a alma é a única forma substancial do corpo. Um corpo que não esteja unido à alma só pode ser chamado de "humano", caso usemos o termo equivocadamente. Trata-se de uma união harmoniosa, ordenada. Diz Tomás: "A disposição do corpo ao qual está unida a alma racional deve [contribuir para] formar um complexo harmonioso" (Comentário ao De Anima, a.8).

O corpo, portanto, não está unido à alma acidentalmente, mas substancialmente. No entanto, para Tomás de Aquino, ele é o coprincípio menos nobre do composto humano, e está para a alma assim como a potência está para o ato e a matéria para a forma:

Se se supóe que a alma intelectiva náo está unida ao corpo como forma, apenas como uma espécie de motor, como sustentavam os platônicos, seria necessário que no homem houvesse outra forma substancial pela qual o corpo, móvel da alma, fosse constituído em seu ser. Mas se a alma intelectiva está unida ao corpo como forma substancial, como já 
demonstramos [Suma Teológica, I, 76, a.1], é impossível que, além dela, se encontre no homem outra forma substancial. [...] É preciso dizer que no homem nâo existe nenhuma outra forma substancial além da alma intelectiva, que contém virtualmente a sensitiva e a nutritiva. (TOMÁS DE AQUINO. Suma Teológica, I, 76, a.4).

Percebe-se claramente a vertente aristotélica de sua filosofia - ele se vale dos conceitos da Metafísica do Estagirita para construir sua filosofia cristá. Aristóteles dissera que o corpo era, de alguma maneira, "informado" por uma forma (Física, IV, 4, 204b). A distância do platonismo do século XII e da noção de corpo como prisâa é enorme.

Seja como for, outro ponto importante com relação ao corpo humano (que, como se disse, só pode ser dito "humano" quando unido à alma, coprincípio superior) é que, para o Aquinate, a alma está em todas as partes do corpo humano:

A alma é forma substancial do corpo. Por isso é necessário que seja forma e ato não apenas do todo substancial, mas de cada uma de suas partes materiais. Deste modo, assim como ao separar-se a alma não podemos mais falar de "homem" nem "animal", a não ser equivocamente, [...] o mesmo devemos dizer com relaçáo à mão, ao olho, à carne, ao osso. [...] Prova disso é que, quando a alma se separa, nenhuma parte do corpo realiza as suas funçōes próprias. (TOMÁS DE AQUINO. Suma Teológica, I, q. 76, a. 8).

Assim, as premissas de Tomás de Aquino em relação ao corpo humano são as seguintes:

1) Ele é coprincípio essencial (e inferior) do ente humano. Sendo em nós, portanto, um elemento essencial, é preciso dizer que sem corpo nấo há homem, propriamente;

2) O corpo está unido substancialmente à alma, coprincípio superior que está para ele assim como a forma está para a matéria;

3) A alma se serve instrumentalmente do corpo não apenas para as operaçôes sensitivas, mas também para as intelectivas. Não é possível, portanto, entender nem querer sem o intermédio do corpo;

4) A alma é a sua única forma substancial, sem a qual sequer ele pode ser dito corpo humano;

5) A alma está em todas as partes do corpo humano. 
A superioridade da beleza espiritual face à corporal - ou, em termos tomistas, a substancialidade da alma em relação ao corpo - é um tópico estético da filosofia medieval. Pelo menos desde Clemente de Alexandria (c. 150-215) esse é um tema recorrente:

A melhor beleza é, em primeiro lugar, a da alma [...] quando está adornada pelo Espírito Santo e os resplendores que emanam d'Ele: a justiça, a prudência, a fortaleza, a temperança, a benevolência e o pudor. Nunca se viu cores táo radiantes como essas. A seguir, deve-se também cultivar a beleza corporal, que é uma harmonia de membros e partes acompanhada da beleza na cor [...] A beleza é a flor espontânea da saúde; a saúde se cultiva dentro do corpo, mas a formosura, ao florescer fora dele, manifesta a beleza da cor. Ao exercitar o corpo, as mais formosas e saudáveis condutas alcançam a genuína e duradoura beleza. (CLEMENTE DE ALEXANDRIA. Pedagogo, III, 11).

\section{Conclusão}

Platão anunciara que o corpo era um empecilho para se chegar à Verdade:

Enquanto tivermos corpo e nossa alma se encontrar atolada em sua corrupçáo, jamais poderemos alcançar o que almejamos. E o que queremos, declaremo-no de uma vez por todas, é a verdade [...] Ao que parece, a única maneira de ficarmos mais perto do pensamento é abstermo-nos o mais possível da companhia do corpo e de qualquer comunicaçáo com ele. (PLATÃO, Fédon, 66b, 67a). 
Imagem 7

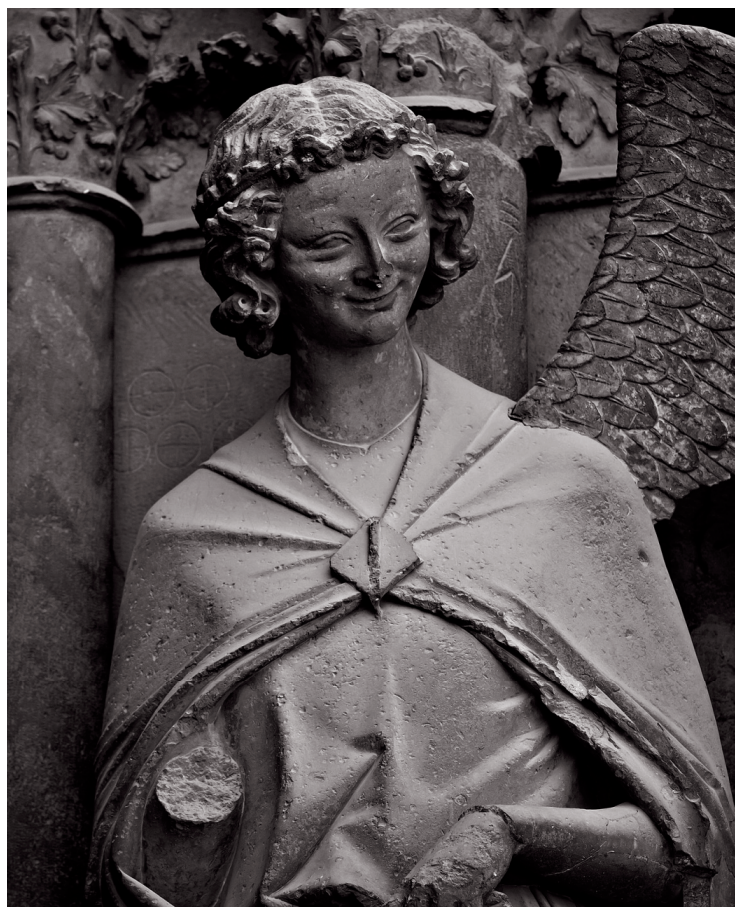

Nietzsche (1844-1900), no outro extremo da história da filosofia ocidental, além de "matar" Deus, também assassinou a alma, corporificando tudo: "Mas o que está desperto e atento diz: - Tudo é corpo, e nada mais; a alma é apenas nome de qualquer coisa do corpo" (Assim falou Zaratustra, Primeira Parte, 4). Entre ambos, a filosofia medieval, com sua glorificação do corpo, mas também disciplina e contenção, sublimação e estetização, idealização e metáfora do mundo.

Dilacerada entre a imanência e a transcendência, a filosofia medieval reservou ao corpo um estatuto ambíguo. De um lado, a influência platônica (e bíblica - Rm 8, 13; 1Cor, 15, 35-53; Fl 3, 20-21), de outro, a aristotélica - e sua coroação com Tomás de Aquino. Não mais percebido como uma prisão, mas um belíssimo palácio da alma, morada a seu serviço, o corpo medieval pôde sorrir. E sorriu. Como o suave e doce anjo da catedral de Reims (séc. 
XIII, imagem 7). Há melhor expressão artística do paradoxo do corpo na Idade Média que aquele delicado (e estoico) sorriso angelical? Entre as lágrimas redentoras e a gargalhada suspeita, o corpo medieval inventou o sorriso singelo, feliz. A história da percepção do corpo é a nossa história, tensão de nosso estar no mundo. A filosofia não poderia deixar de considerá-lo.

\begin{abstract}
A beleza do corpo consiste em que o homem tenha membros corporais bem proporcionados e uma certa claridade da cor. Do mesmo modo, a beleza espiritual consiste em que a conduta do homem, entendida como o conjunto de seus atos, seja bem proporcionada e conforme certa claridade espiritual da razão. (TOMÁS DE AQUINO. Suma Teológica, IIa-Ilae, q. 145, a. 2c).
\end{abstract}

COSTA, Ricardo Luiz Silveira da. The aesthetics of the body in the philosophy and art of the Middle Ages: text and image. Trans/Form/Ação, Marília, v. 35, p. 161-178, 2012. Edição Especial.

\begin{abstract}
The concept of beauty, and its consequent aesthetic enjoyment, has varied according the transformations of human societies over time. During the Middle Ages there were different conceptions, in both philosophy and art, of what the role of the body is in the hierarchy of aesthetic values. Our purpose is to present the aesthetic of the body that some medieval philosophers developed in their treatises (especially Isidore of Seville, Hildegard of Bingen, John of Salisbury, Bernard of Clairvaux and Thomas Aquinas), as well as some bodily representations of medieval images (illuminations and sculptures). We thus examine the issue in three ways: a) the body as a prison of the soul, $\mathbf{b}$ ) the body as an instrument, and c) the body as degradation.
\end{abstract}

KEYWORDS: Aesthetic. Body. Middle Ages. Medieval Philosophy.

\title{
REFERENCIAS
}

CLEMENTE DE ALEXANDRIA. El pedagogo. (Introducción por Ángel Castiñeira Fernández. Traducción y notas por Joan Sariol Diaz). Madrid: Gredos, 1988.

HILDEGARDA DE BINGEN. Libro de las Obras Divinas. Liber Divinorum Operum, Tradución de Rafael Renedo. 2007 (inédita, realizada por iniciativa de Hildegardiana). Disponível em: http://www.hildegardiana.es/32divope/index.html. Acesso em: 30.08.2012.

JUAN DE SALISBURY. Policraticus (ed. IADERO, Miguel Angel; GARCIA, Matias; ZAMARRIEGO, Tomas). Madrid: Nacional, 1984. 
NIETZSCHE, Friedrich. Assim falou Zaratustra. São Paulo: Companhia das Letras, 2011. PERNOUD, Régine. Luz sobre a Idade Média. Lisboa: Publicaçôes Europa-América, s/d. PLATÃO. Diálogos (Protágoras - Górgias - Fedão) (tradução do grego de Carlos Alberto Nunes). Belém: Editora da UFPA, 2002.

SAN BERNARDO DE CLARAVAL. Obras completas. Madrid: BAC, 1987-1993 (sete volumes).

SAN ISIDORO DE SEVILLA. Etimologías. Madrid: Edición Bilingüe Latin-Español, 2004

TOMÁS DE AQUINO. Summa theologiae. Roma: Edizioni Paoline, 1962.

TOMÁS DE AQUINO. Super librum Dionysii De divinis nominibus expositio. Romae: Marietti, 1950. 
COSTA, R. L.S. 